\title{
The impact of childcare-group situational age composition on caregiver-child interactions
}

\author{
Tatiana Diebold (iD ${ }^{\mathrm{a}, \mathrm{b}}$ and Sonja Perren (iD) ${ }^{\mathrm{a}, \mathrm{c}}$ \\ aDevelopment and Education in Early Childhood, Thurgau University of Teacher Education, \\ Kreuzlingen, Switzerland; 'bepartment of Psychology, Swiss Distance University, Brig, \\ Switzerland; 'Empirical Educational Research, University of Konstanz, Konstanz, Germany
}

\begin{abstract}
The present study investigated the role of situational age composition in the quality of caregiving. We specifically examined the impact of age range, the number of children present younger than 18 months, and median age, on the caregiver-child interaction quality under unique conditions of flexible and age-heterogeneous childcare. Caregiver-child interactions in nine childcare groups were observed over four mornings ( $N$ observation cycles $=144$ ). The results from multilevel structural equation modelling showed that wide age range and a higher number of very young children present were related to lower quality of observed behavioural, emotional and learning support. Most importantly, the findings suggest that the effects of age range can be explained by the number of children less than 18 months old. Implications for further research and mixed-age programmes' practice and policy are discussed.
\end{abstract}

KEYWORDS Childcare; age composition; age range; number of infants; caregiver-child interactions

There is a large research field investigating the role of childcare in children's learning, social-emotional development and psychosocial adjustment. Most studies on these associations suggest that spending time in high-quality childcare has a positive impact on child outcomes (Ahnert \& Lamb, 2011; Burchinal, Vandergrift, Pianta, \& Mashburn, 2010; Campbell, Pungello, MillerJohnson, Burchinal, \& Ramey, 2001; Duncan, 2003; NICHD, 2006; Tietze et al., 2012; Vandell, Belsky, Burchinal, Steinberg, \& Vandergrift, 2010). Childcare quality is considered to be a multidimensional construct that can be measured by assessing both structural and process characteristics (Howes et al., 2008; Layzer \& Goodson, 2006; Boo, Araujo, \& Tomé, 2016; Phillips, Mekos, Scarr, McCartney, \& Abbott-Shim, 2000). Structural childcare quality refers to features such as group size, caregiver-to-child ratio, and caregivers' general 
level of qualification. Process quality in childcare refers to dynamic aspects such as caregivers' behaviour, interactions between caregivers and children and between children themselves, and curriculum implementation (Howes et al., 2008; Boo et al., 2016; Slot, Leseman, Verhagen, \& Mulder, 2015; Thomason \& La Paro, 2009; Viernickel \& Fuchs-Rechlin, 2016). Cumulative research findings in and beyond the USA indicate that process variables are consistently and long-term associated with children's cognitive, social and emotional development (Gialamas, Mittinty, Sawyer, Zubrick, \& Lynch, 2014; Sylva, Melhuish, Sammons, Siraj-Blatchford, \& Taggart, 2004; Vandell et al., 2010). Moreover, childcare researchers emphasize high-quality social interactions between caregiver and children as the most important determinant of the quality of early education and care (Burchinal et al., 2010; Curby, Brock, \& Hamre, 2013; Curby et al., 2009; Howes et al., 2008; Mashburn et al., 2008; Peisner-Feinberg et al., 2001; Wilson, Pianta, \& Stuhlman, 2007).

A number of studies have investigated the relation between structural characteristics and process quality based on the assumption that structural childcare quality predicts how teachers provide care and education, and whether they are sensitive, reliable, and emotionally available for children. Some studies provided evidence that positive caregiving was more common when group size and child-adult ratio were smaller (Cryer, Tietze, Burchinal, Leal, \& Palacios, 1999; Helmerhorst, Riksen-Walraven, Gevers DeynootSchaub, Tavecchio, \& Fukkink, 2015; NICHD, 2006; Phillips et al., 2000; Reyhing, Frei, Burkhardt Bossi, \& Perren, 2019). Caregiver education and training have also been found to be associated with higher quality caregiver skills (Burchinal, Cryer, Clifford, \& Howes, 2002; Burchinal, Howes, \& Kontos, 2002; Campbell \& Milbourne, 2005; Fukkink \& Lont, 2007; Perren et al., 2017). Other studies, however, have found only weak associations between childcare structural quality and caregiving quality, or have failed to confirm these associations at all (Burchinal et al., 2002; Gialamas et al., 2014; Howes et al., 2008; Pianta et al., 2005; Slot et al., 2015).

Age composition is mentioned in the research as a further relevant characteristic of childcare, since there is a high degree of variability in childcare group composition within and between countries. While some childcare programmes favour a traditional grouping by age, other centres use mixedage grouping that provides an extended age range within the same group. Such family-like programmes are highly flexible and require fewer staff, classrooms, and schedules. At the same time, mixed-age grouping may have consequences for both child engagement and the quality of caregiving. To date, however, little research has been done to examine the effects of 
peer-group age compositions in the context of early education and childcare, since only a few countries (e.g., Germany, the Netherlands) adopt an extended age range and include children under the age of three in regular preschool classes (Helmerhorst et al., 2015; Sommer \& Sechtig, 2016). Most previous studies comparing multi-age and same-age settings focused on children's behavioural outcomes, while research on associations between peer-group age composition and caregiver behaviour is very limited. Overall, research provides evidence that caregiving in mixed-age groups is of lower quality (Tietze et al., 2013). Sundell (1994) found that age range negatively influenced the quality of interaction between preschool teachers and children. Teachers provided fewer teacher-guided activities and less elaborated instructions in groups with a wide age range. Sommer and Sechtig (2016) have shown that the extension of the age range in the group is a strong predictor of lower interaction quality between caregivers and children. To shed light on this negative effect of a wide age range, the authors additionally included the number of children aged under 36 months in the analysis and showed that the presence of even a single child younger than 36 months of age had a negative impact on the quality of caregiving (Sommer \& Sechtig, 2016). This result is consistent with the findings of a Dutch study that investigated mixed-age groups comprising children aged from 0 to 4 years (de Schipper, Riksen-Walraven, \& Geurts, 2007). The study indicated that the number of infants in the group is a significant predictor of caregiving quality: groups with fewer children aged under 24 months receive a better quality of care. A further study in a Dutch childcare context demonstrated that both caregivers' sensitive responsiveness and their educational skills were lower in infant groups ( $0-2$ years) than in preschool groups (2-4 years) or even in mixed-age groups (0-4 years; Helmerhorst et al., 2015). Some studies recognizing age composition as a potential determinant of caregiver behaviour in childcare centres reported that a higher mean age in the childcare group correlates with higher-quality caregiving behaviour (De Schipper, Marianne Riksen-Walraven, \& Geurts, 2006; Kuger \& Kluczniok, 2009). To summarize, previous research provides some evidence that a wide age range, higher numbers of infants in the group, and a lower mean group age are all associated with lower caregiver-child interaction quality.

\section{Childcare centres in Switzerland}

In Swiss childcare centres, children are usually placed in mixed-age groups with a wide range of ages from four months (end of maternity leave) up to 
five years (start of mandatory kindergarten linked to the primary school). Additionally, childcare in Switzerland is characterized by a high degree of flexibility in terms of children's attendance schedules. Parents often work part-time and so choose the days of attendance depending on their individual job-related needs, which may also vary from week to week and from month to month. Thus, it is possible for individual children to attend childcare on single days ( 1 to 5 days a week), in the morning or afternoon, or for the whole day. The majority of children who attend childcare do so part-time for two or three days a week (Swiss Federal Statistical Office, 2014). The average group size is about 12 children, but a significant number of available childcare places are shared by two or more children (e.g., one child uses a childcare place on Monday morning, the other on Monday afternoon). The Swiss Childcare Association, which provides guidelines and standards on caregiving quality in childcare, takes children's age and staff qualifications into account when calculating the caregiver-child ratio (Kibesuisse, 2016). The majority of professional caregivers in Swiss childcare have completed an apprenticeship of three years, which combines two-day school attendance and three-day in-service training per week. Caregivers only rarely hold a college or university degree. A high percentage of trainees (i.e., young persons who attend a first year-long internship after completion of mandatory schooling) and apprentices work alongside qualified professional caregivers (Perren et al., 2017; Stamm, 2009).

On the one hand, this way of organizing childcare not only offers advantages for childcare providers, but also helps parents to better reconcile the needs of family and career. On the other hand, flexible childcare results in a high degree of fluctuation of makeup of the childcare group and permanent changes in the situational group composition (e.g., in age composition, group size and, therefore, behaviour patterns of the peer group). Such a dynamic may have an impact on the quality of caregiving, as caregivers constantly face the challenge of matching and adapting their resources to the different needs and interests of specific age groups (e.g., infants, toddlers, and pre-schoolers) at the same time.

The current study included different aspects of peer-group age composition and investigated their impact on caregiver-child interactions using multivariate multilevel analyses under unique, particularly favourable conditions of flexible and age-heterogeneous childcare. A recent study from Switzerland has shown that situational group characteristics, such as group activities and the number of children present, are stronger predictors of caregiver-child interaction quality than other structural features such as 
group size (Reyhing et al., 2019). The present study thus explicitly focused on the situational age composition of the childcare group.

\section{Research questions and hypotheses}

This study aimed to investigate the role of situational peer-group age composition (including age range, the number of children present younger than 18 months, and median age) in the quality of caregiverchild interactions, measured by emotional and behavioural support and engaged support for learning. Based on previous research, we hypothesized that: (a) situational peer-group age range is negatively associated with caregiver-child interaction quality, and (b) median age is positively associated with caregiver-child interaction quality. As appropriate care for infants constitutes a challenge for caregivers, especially in mixed-age settings, it is necessary to account for the number of very young children present. Accordingly, we further aimed to examine peer-group age range more closely and to explore whether the effects of age range can be explained by the number of children present aged under 18 months.

\section{Method}

\section{Study participants}

Nine groups from four different childcare centres from the German-speaking part of Switzerland participated in the present study, with a total of 54 children ( $46 \%$ female, age in years: $M=3.5, S D=0.5$ ). All childcare centres were recruited using emails and follow-up telephone calls. After obtaining active agreement for study participation from childcare directors and caregivers from the selected groups, all parents were informed in writing about the study's goals, procedure, and assessment timing, as well as being offered the opportunity to withdraw from participation at any time with no negative consequences.

\section{Study measures and procedure}

\section{Assessment of caregiver-child interactions}

To assess the quality of interactions between caregivers and children, trained observers visited each childcare group over four mornings (from 8:00 a.m. to 12:00 noon). The data collectors conducted live observations and rated nearly all the group activities that normally take place during a day, applying the 
Classroom Assessment Scoring System (CLASS: Toddler; La Paro, Hamre, \& Pianta, 2012). CLASS is a frequently used and well-validated observational instrument developed to assess classroom quality in toddlers and pre-school age children, focusing on process quality and measuring the quality of interactions between caregivers/teachers and children as the average experience of all children in group settings. The CLASS Toddler includes eight dimensions organized into two domains of teacher-child interactions: Emotional and Behavioural Support (Positive Climate, Negative Climate, Teacher Sensitivity, Regard for Child Perspectives, Behaviour Guidance) and Engaged Support for Learning (Facilitation of Learning and Development, Quality of Feedback, and Language Modelling). One of two observers made observations in classrooms for 15 minutes and then scored each CLASS dimension on a seven-point scale. Higher ratings indicated higher quality and more frequent positive caregiver-child interactions within each dimension (except the dimension of negative climate, for which higher ratings indicated a higher level of negative interactions between caregivers and children). In line with the manual recommendations, data from up to four 20minute cycles across four consecutive days were gathered $(M=4.90$; $S D=.85$; range $=4$ to 6 ; total $320-480$ minutes observation time for each childcare group).

Following the two-domain structure, we calculated summary scores by averaging rating scores within each domain in each observation cycle. Cronbach's alpha coefficients for the CLASS domain scores were as follows: Emotional and Behavioural Support $a=.69$; Engaged Support for Learning $a=.80$. The results of descriptive statistics indicated furthermore very low variance within the dimension Negative Climate: only $2 \%$ of all cycles were rated in the mid range (codes 3 or 4), whereas $98 \%$ of observations were assigned a code within the low range (codes 1-2), indicating a low degree of average negative experience with caregivers in the observed groups (Pakarinen et al., 2010; Perren, Frei, \& Herrmann, 2016; Reyhing et al., 2019; von Suchodoletz, Fäsche, Gunzenhauser, \& Hamre, 2014). We thus excluded Negative Climate from further analyses, which considerably improved the internal consistency of Emotional and Behavioural Support ( $a=.79$ ).

\section{Assessment of age composition (peer-group age range, number of infants, and median age)}

To assess the situational peer-group age composition, observers recorded the number and names of children present for the majority of time in each observation cycle. Based on these name lists the peer-group age range, 
number of children younger than 18 months of age, and median age were calculated. Age range was defined as the difference in age between the oldest and the youngest child present during the observation cycle. Thus, a wider age range indicated a larger age difference between the oldest and the youngest child.

\section{Data analytic approach}

In order to examine the impact of situational childcare-group age composition on the quality of caregiver-child interactions, we conducted the analyses using the cycle scores instead of computing mean scores for each childcare group.

The data from the present study had a two-level structure, with repeated measures (i.e., observation cycles) sampled within childcare groups. To account for the nested nature of the data, multilevel structural equation modelling (MSEM) was run using Mplus 7.31 (Muthén \& Muthén, 2012).

Four models were run to investigate the associations of interest. The initial models included situational age range and median age at level 1 (cycle-level) as predictors of emotional and behavioural support (Model 1) and engaged support of learning (Model 2). To examine age range more closely, we then investigated the effect of the number of infants present by adding the number of children aged under 18 months in both initial models (Model 3 and Model 4). All predictors were grand mean centred. Each of the multilevel structural equation models was constructed as a random intercept and random slope model. In this model, the association between predictors and outcome variable varied across childcare groups. The covariance between intercepts and slopes was also specified in the models (Aguinis, Gottfredson, \& Culpepper, 2013; Geiser, 2011).

It must be noted that we conducted the models without adding any covariates due to the small number of clusters $\left(N_{\text {childcare groups }}=9\right)$ and as the maximum number of parameters was reached.

\section{Results}

\section{Preliminary results}

Table 1 provides variance components and intra-class correlations (ICCs) for both CLASS domains. The results indicate that most of the variance originated from differences between observation cycles. However, the between-level variances are also considerable (>.10) and the values of 
Table 1. Variance components and intra-class correlations (ICCS) for CLASS domains.

\begin{tabular}{lcc}
\hline & Emotional and Behavioural Support & Engaged Support for Learning \\
\hline $\begin{array}{l}\text { Variance components } \\
\text { Level 1: cycle }\end{array}$ & $0.740^{* * *}$ & $0.703^{* * *}$ \\
$\quad$ Level 2: childcare group & $0.115^{* *}$ & $0.379^{*}$ \\
ICC coefficients & .134 & .349 \\
Level 2: childcare group & .134 & \\
\hline
\end{tabular}

ICC: Level 2 variance divided by total variance.

$\mathrm{N}_{\text {Level } 1}=144$ (CLASS observation cycles), $\mathrm{N}_{\text {Level } 2}=9$ (childcare groups).

${ }^{*} p<.05{ }^{* *} p<.01{ }^{* * *} p<.001$

Table 2. Descriptive statistics for the study variables.

\begin{tabular}{lcccc}
\hline & & & \multicolumn{2}{c}{ Range } \\
\cline { 4 - 5 } Variable & Mean & SD & Min & Max \\
\hline Emotional and Behavioural Support & 4.52 & 0.93 & 2.50 & 6.50 \\
Engaged Support for Learning & 2.48 & 1.05 & 1.00 & 5.67 \\
Age range & 2.58 & 0.86 & 0 & 4.20 \\
Median age & 3.02 & 0.49 & 1.67 & 4.08 \\
Number of infants & 0.66 & 0.92 & 0 & 4 \\
\hline
\end{tabular}

Number of infants $=$ number of children younger than 18 months present.

the ICCs suggest the dependence of scores between observation cycles in the same childcare group. In short, the results provided evidence for a nested data structure that required two-level modelling, with observation cycles $\left(N_{\text {Level } 1}=144\right)$ nested within childcare groups $\left(N_{\text {Level } 2}=9\right)$.

Table 2 shows mean scores, standard deviations, and ranges for the study variables. The relatively high ratings for emotional and behavioural support $(M=4.52)$ and low to mid level of engaged support for learning $(M=2.48)$ are comparable to the findings of previous international and Swiss studies (La Paro, Williamson, \& Hatfield, 2014; Perren et al., 2016; Reyhing et al., 2019; Slot, Boom, Verhagen, \& Leseman, 2017; von Suchodoletz et al., 2014).

Table 3 provides bivariate associations between the study variables. Age range was significantly and negatively associated with the quality of emotional and behavioural support $(r=-.24, p<.01)$. Further, the number of infants was found to be negatively associated with both emotional and

Table 3. Correlations between all study variables.

\begin{tabular}{llcccc}
\hline \multicolumn{1}{c}{ Variable } & 2 & 3 & 4 & 5 \\
\hline 1 & EBS & $.65^{* * *}$ & $-.24^{* *}$ & .08 & $-.24^{* *}$ \\
2 & ESL & & -.13 & -.01 & $-.19^{*}$ \\
3 & Age range & & $-.20^{* * *}$ & $.66^{* * *}$ \\
4 & Median age & & & $-.41^{* * *}$ \\
5 & Number of infants & & & \\
\hline EBS $=$ Emotional and Behavioural & Support; ESL = Engaged Support for Learning. Number of \\
infants $=$ number of children younger than 18 months present. & & \\
${ }^{*} p<.05{ }^{* *} p<.01{ }^{* * *} p<.001$ & &
\end{tabular}


behavioural support $(r=-.24, p<.01)$ and engaged support for learning $(r=-.19, p<.05)$, indicating that caregivers provided less positive and supportive behaviour the greater the number of children younger than 18 months present.

\section{Main analyses}

Table 4 presents the results of the multilevel structural equation modelling including situational peer-group age range and median age as predictors of the caregiver-child interaction quality. The results show that age range negatively predicted both the observed quality of emotional and behavioural support $(b=-.361, p<.001)$ and engaged support for learning $(b=-.341, p<.01)$, indicating that caregivers provided more positive and supportive behaviour when the children were closer in age.

Table 5 shows the results of the multilevel structural equation modelling including situational peer-group age range, median age, and the number of infants present, as a further predictor of the quality of caregiver-child interactions. The results suggest that after adding the number of infants present to the initial model, the negative association between age range and emotional and behavioural support was still marginally significant $(b=-.193$, $p=.07$ ). The number of children under 18 months was negatively and almost significantly related to the quality of emotional and behavioural support $(b=-.283, p=.06)$. For engaged support for learning, the negative impact of age range was no more significant after the number of infants was included in the model $(b=-.174, p=.15)$. The number of children aged under 18 months, however, negatively predicted the quality of engaged support for learning $(b=-.268, p<.01)$.

Table 4. Initial models (Model 1 and Model 2): results of MSEM for associations between situational age composition and caregiver-child interactions.

\begin{tabular}{|c|c|c|c|c|}
\hline \multirow[b]{2}{*}{ Predictor Variable } & \multicolumn{2}{|c|}{ Emotional and Behavioural Support } & \multicolumn{2}{|c|}{ Engaged Support for Learning } \\
\hline & $b$ & $S D$ & $b$ & $S D$ \\
\hline \multicolumn{5}{|l|}{ Level 1: observation cycle } \\
\hline Intercept & $4.561^{* * *}$ & 0.143 & $2.542^{* * *}$ & 0.213 \\
\hline Age range & $-0.361^{* * *}$ & 0.098 & $-0.341^{* *}$ & 0.116 \\
\hline Median age & 0.222 & 0.155 & 0.117 & 0.147 \\
\hline \multicolumn{5}{|l|}{ Variance components } \\
\hline Level 1 variance & $0.655^{* * *}$ & 0.061 & $0.639^{* * *}$ & 0.119 \\
\hline Intercept (level 2) variance & 0.160 & 0.117 & 0.469 & 0.300 \\
\hline Slope (level 2) variance & 0.005 & 0.045 & 0.037 & 0.056 \\
\hline Intercept-slope covariance & -0.011 & 0.023 & $-0.126^{*}$ & 0.065 \\
\hline ICC (level 2) & 0.179 & - & 0.379 & - \\
\hline
\end{tabular}

ICC: single-level variance divided by total variance. $\mathrm{N}_{\text {Level } 1}=144$ (CLASS observation cycles),

$\mathrm{N}_{\text {Level } 2}=9$ (childcare groups). Unstandardized coefficients are presented.

${ }^{*} p<.05{ }^{* *} p<.01{ }^{* *} p<.001$ 
Table 5. Final models (Model 3 and Model 4): results of MSEM for associations between situational age composition and caregiver-child interactions after adding the number of infants.

\begin{tabular}{|c|c|c|c|c|}
\hline \multirow[b]{2}{*}{ Predictor Variable } & \multicolumn{2}{|c|}{ Emotional and Behavioural Support } & \multicolumn{2}{|c|}{ Engaged Support for Learning } \\
\hline & $b$ & $S D$ & $b$ & $S D$ \\
\hline \multicolumn{5}{|l|}{ Level 1: observation cycle } \\
\hline Intercept & $4.533^{* * *}$ & 0.163 & $2.523^{* * *}$ & 0.214 \\
\hline Age range & $-0.193 \dagger$ & 0.108 & -0.174 & 0.121 \\
\hline Median age & 0.075 & 0.151 & -0.001 & 0.145 \\
\hline Number of infants & $-0.283 \dagger$ & 0.151 & $-0.268^{* *}$ & 0.092 \\
\hline \multicolumn{5}{|l|}{ Variance components } \\
\hline Level 1 variance & $0.630^{* * *}$ & 0.068 & $0.621^{* * *}$ & 0.121 \\
\hline Intercept (level 2) variance & $0.189 \dagger$ & 0.107 & 0.460 & 0.321 \\
\hline Slope (level 2) variance & 0.003 & 0.111 & 0.019 & 0.084 \\
\hline Intercept-slope covariance & 0.016 & 0.039 & -0.086 & 0.063 \\
\hline ICC (level 2) & 0.185 & - & 0.371 & - \\
\hline
\end{tabular}

Number of infants $=$ number of children younger than 18 months present. ICC: single-level variance divided by total variance. $\mathrm{N}_{\text {Level }} 1=144$ (CLASS observation cycles), $\mathrm{N}_{\text {Level } 2}=9$ (childcare groups). Unstandardized coefficients are presented.

$\dagger p<.08 * * p<.01{ }^{* * *} p<.001$

There was no significant association between peer-group median age and quality of caregiver-child interactions.

\section{Discussion}

This study examined the associations between situational peer-group age composition and caregiver behaviour in terms of what caregivers provide through their interactions with children. As hypothesized, wide age range was related to lower quality of observed emotional and behavioural support and engaged support for learning. However, when considering the number of very young children present, the results yielded the following picture: the number of infants present was found to be associated with the quality of caregiver-child interactions. As expected, the higher the actual number of children younger than 18 months present during the observation cycle, the lower the level of emotional and behavioural support and engaged support for learning provided by caregivers. At the same time, the impact of age range was only marginally significant for emotional and behavioural support, and no more significant for engaged support for learning. These findings indicate that the negative association between age range and caregiver-child interaction quality can be explained by the actual number of very young children present. This effect was particularly evident in the quality of engaged support for learning. Numerous international studies have reported a generally moderate level of emotional and behavioural support, and a rather low level of engaged support for learning 
(Helmerhorst et al., 2015; La Paro et al., 2014; Perren et al., 2016; Reyhing et al., 2019; Slot et al., 2017; von Suchodoletz et al., 2014). Our study provided further evidence for these findings and indicated that children usually experience positive caregiving, sensitivity and support in regulating their emotions and behaviours. With regard to engaged support for learning, however, there is still significant potential for improvement: caregivers are unlikely to provide high-quality learning support, such as language modelling or feedback. The present study also indicated that caregiving becomes more complicated to plan and implement when several age groups are present at the same time, and particularly so in settings with a greater number of very young children. The huge developmental differences between infants, toddlers, and pre-schoolers require activities to be adjusted to different children's needs. This challenging situation seems to limit caregivers' opportunities for providing age- and developmentally appropriate curricula and encouraging children's learning. We assume furthermore that infants' special needs, such as emotional support, feeding, cradling them to sleep or changing nappies, often interrupt activities with older children.

The hypothesis that the median age of the peer group positively predicts caregivers' behaviour was not supported by our results. This finding suggests that in the current situation, the age range and especially the number of infants present seem to be more relevant than the situational mean age - in contrast to previous studies, which investigated general mean age without considering other aspects of age composition (De Schipper et al., 2006; Kuger \& Kluczniok, 2009).

\section{Strengths and limitations}

Our study has some limitations that should be taken into account, and that indicate directions for future research. The small sample size, in particular the small number of clusters (9 childcare groups), led to statistical limitations and an inability to consider confounding variables such as group size and caregiver-child ratio, which have often been found to be associated with caregiving quality (Helmerhorst et al., 2015; Reyhing et al., 2019). However, by analysing the cycle scores (144 observation cycles), we increased statistical power. The study design does not allow us to conclude from the results whether mixed-age grouping or grouping by age is preferable. For this, studies with an appropriate sample size and comparing mixed-age and same-age childcare programmes are needed. Moreover, longitudinal studies of associations between different features 
of age composition and individual child outcomes are required. Previous research has provided mixed findings on the benefits and disadvantages of mixed-age and same-age groupings for children's cognitive and social development (for an overview, see Moller, Forbes-Jones, \& Hightower, 2008).

Another important issue for further research is the role played by various activity settings throughout the day in the relationship between age composition and process quality. Reyhing et al. (2019) have shown that children experienced higher quality learning support during teacher-guided group activities compared to free choice, meals, and routings/transitions. Few studies provided evidence that children's engagement also varies according to group activity setting. Children's interactions with teachers were more positive during teacher-structured activity time as compared to childdirected activities, indicating that teachers are less available and children have fewer opportunities to engage or communicate with caregivers in free play. On the contrary, in child-directed activity settings, children showed significantly more positive interactions with peers as they had more opportunity to engage with other children. (Booren, Downer, \& Vitiello, 2012; Vitiello, Booren, Downer, \& Williford, 2012).

In addition, we argue that caring for infants absorbs a substantial part of caregivers' capacity, often to the detriment of older children. However, it is important to note that CLASS ratings are based on the average experience of all the children in the group. Different CLASS versions have been developed to assess classroom quality in infants, toddlers and pre-school age children through to third grade classrooms and are designed for same-age groups. CLASS Toddler applied in this study focuses on the target group of children from 15-36 months (La Paro et al., 2012). Therefore, it is not possible to make any statements about the quality of caregiving for different age groups, especially from the perspective of very young children, which might be interesting to examine in further studies. Previous research has suggested that infants are more likely to receive lower-quality caregiving (De Schipper et al., 2006; Helmerhorst et al., 2015).

Despite the limitations mentioned above, the present study has some methodological strengths and provides an important contribution to the existing evidence in several ways. First, we investigated the role of age composition under unique conditions of flexible and age-heterogeneous childcare with an extended and constantly changing age range. By analysing cycle scores, we not only increased the statistical power, but also explicitly focused on differences between observation cycles. These 
conditions enabled us to investigate the impact of situational age composition. Second, we considered different aspects of age composition mentioned in existing studies and examined them, conducting multilevel structural equation modelling to take into account the multilevel nature of the data. Further, we investigated age composition more closely and were able to show that the number of infants present seems to be more important for the quality of caregiving than does the breadth of peergroup age range in mixed-age groupings. Thus, the results demonstrated that the features of peer-group age composition in childcare should be viewed in a more differentiated way than only considering the breadth of age difference.

\section{Implications for policy and practice}

Our findings are interesting not only for further research but also in terms of potential starting points for improving the quality of interactions between caregivers and children in mixed-age settings. Multi-age programmes in early education and care should be carefully monitored, as the consequences of mixed-age grouping are not solely beneficial: it can also have a negative effect on interaction quality between caregivers and children. In line with the previous guidelines provided by Swiss Childcare Association (Kibesuisse, formerly named KiTaS, 2008), children under 18 months of age require more intensive care and monitoring than older children and are weighted with a factor 1.5 (i.e., one child younger than 24 months of age occupies 1.5 childcare places). Kibesuisse recommended limiting the number of infants in a mixed-age group to 2 and the total group size to a maximum of 10 to 12 children. As already mentioned, in the revised guidelines of Kibesuisse (2016) the regulation of caregiver-child ratio is dependent on the age of children present that might contribute to the quality of caregiving. Unfortunately, children's age is no longer taken into account when calculating the maximum group size. Our results, however, suggest that the number of very young children present is relevant to the learning support provided by caregivers. We conclude therefore that there is a need for clear guidelines on the maximum number of infants and total group size, depending on childcare-group age characteristics.

Based on our results we want to highlight the importance of temporary but regular grouping by age within a general mixed-age structure, in order to provide age- and developmentally appropriate curricula. In their work with a broader variety of age groups, caregivers should address 
toddlers' and pre-schoolers' interests and educational needs by planning and organizing times without babies and infants and giving them a diversity of learning activities.

From the points discussed above, it follows that caregiver vocational training and staff qualification need more attention. Training programmes should prepare childcare professionals for working with various age groups within mixed-age settings in different domains of care. The low scores for developmental and learning support found by various international studies (La Paro et al., 2014; Reyhing et al., 2019; Slot et al., 2017), particularly for interactions with very young children (Helmerhorst et al., 2015), encourage policy makers and childcare providers to improve the level of caregivers' skills through validated programmes and opportunities for professional development with a specific focus on caregivers' educational capacity.

\section{Acknowledgments}

The authors would like to acknowledge all students involved in data collection. Furthermore, we thank all caregivers, children and parents for their participation in the study.

\section{Disclosure statement}

No potential conflict of interest was reported by the authors.

\section{ORCID}

Tatiana Diebold (D) http://orcid.org/0000-0002-4137-6157

Sonja Perren (iD http://orcid.org/0000-0002-7916-4037

\section{References}

Aguinis, H., Gottfredson, R. K., \& Culpepper, S. A. (2013). Best-practice recommendations for estimating cross-level interaction effects using multilevel modeling. Journal of Management, 39(6), 1490-1528.

Ahnert, L., \& Lamb, M. 2011. Öffentliche Tagesbetreuung auf dem Prüfstand entwicklungspsychologischen Forschung. In $\mathrm{H}$. Keller (Ed.), Handbuch der Kleinkindforschung (pp. 331-364). Retrieved from https://ilias.ub.uni-konstanz.de/ ilias/repository.php?ref_id=158340\&cmd=sendfile.

Booren, L. M., Downer, J. T., \& Vitiello, V. E. (2012). Observations of children's interactions with teachers, peers, and tasks across preschool classroom activity settings. Early Education \& Development, 23(4), 517-538. 
Burchinal, M., Howes, C., \& Kontos, S. (2002). Structural predictors of child care quality in child care homes. Early Childhood Research Quarterly, 17(1), 87-105.

Burchinal, M., Vandergrift, N., Pianta, R., \& Mashburn, A. (2010). Threshold analysis of association between child care quality and child outcomes for low-income children in pre-kindergarten programs. Early Childhood Research Quarterly, 25(2), 166-176.

Burchinal, M. R., Cryer, D., Clifford, R. M., \& Howes, C. (2002). Caregiver training and classroom quality in child care centers. Applied Developmental Science, 6(1), 2-11.

Campbell, F. A., Pungello, E. P., Miller-Johnson, S., Burchinal, M., \& Ramey, C. T. (2001). The development of cognitive and academic abilities: Growth curves from an early childhood educational experiment. Developmental Psychology, 37(2), 231-242.

Campbell, P. H., \& Milbourne, S. A. (2005). Improving the quality of infant-toddler care through professional development. Topics in Early Childhood Special Education, 25 (1), 3-14.

Cryer, D., Tietze, W., Burchinal, M., Leal, T., \& Palacios, J. (1999). Predicting process quality from structural quality in preschool programs: A cross-country comparison. Early Childhood Research Quarterly, 14(3), 339-361.

Curby, T. W., Brock, L. L., \& Hamre, B. K. (2013). Teachers' emotional support consistency predicts children's achievement gains and social skills. Early Education and Development, 24(3), 292-309. (2013-10629-002).

Curby, T. W., LoCasale-Crouch, J., Konold, T. R., Pianta, R. C., Howes, C., Burchinal, M., ... Barbarin, O. (2009). The relations of observed Pre-K classroom quality profiles to children's achievement and social competence. Early Education and Development, 20(2), 346-372.

De Schipper, E. J., Marianne Riksen-Walraven, J., \& Geurts, S. A. E. (2006). Effects of child-caregiver ratio on the interactions between caregivers and children in child-care centers: An experimental study. Child Development, 77(4), 861-874.

de Schipper, E. J., Riksen-Walraven, J. M., \& Geurts, S. A. E. (2007). Multiple determinants of caregiver behavior in child care centers. Early Childhood Research Quarterly, 22(3), 312-326.

Duncan, G. J. (2003). Modeling the impacts of child care quality on children's preschool cognitive development. Child Development, 74(5), 1454-1475.

Fukkink, R. G., \& Lont, A. (2007). Does training matter? A meta-analysis and review of caregiver training studies. Early Childhood Research Quarterly, 22(3), 294-311.

Geiser, C. (2011). Datenanalyse mit Mplus: Eine anwendungsorientierte Einführung. Retrieved from http://www.springer.com/springer+vs/psychologie/book/9783-531-18002-1

Gialamas, A., Mittinty, M. N., Sawyer, M. G., Zubrick, S. R., \& Lynch, J. (2014). Child care quality and children's cognitive and socio-emotional development: An Australian longitudinal study. Early Child Development and Care, 184(7), 977-997.

Helmerhorst, K. O. W., Riksen-Walraven, J. M. A., Gevers Deynoot-Schaub, M. J. J. M., Tavecchio, L. W. C., \& Fukkink, R. G. (2015). Child care quality in The Netherlands over the years: A closer look. Early Education and Development, 26(1), 89-105.

Howes, C., Burchinal, M., Pianta, R., Bryant, D., Early, D., Clifford, R., \& Barbarin, O. (2008). Ready to learn? Children's pre-academic achievement in pre-kindergarten programs. Early Childhood Research Quarterly, 23(1), 27-50. 
Kibesuisse (Verband Kinderbetreuung Schweiz) [Swiss Childcare Association]. (2008). Richtlinien für die Betreuung von Kindern in Kindertagesstätten [Guidelines for the care of children in daycare centers]. Retrieved from https://kibesuisse.ch/fileadmin/ user_upload/Kibesuisse/Publikationen/DE_KiTaS_Richtlinien_2008.pdf

Kibesuisse (Verband Kinderbetreuung Schweiz) [Swiss Childcare Association]. (2016). Richtlinien für die Betreuung von Kindern in Kindertagesstätten [Guidelines for the care of children in daycare centers]. Retrieved from https://kibesuisse.ch/fileadmin/ Dateiablage/kibesuisse_Publikationen_Deutsch/kibesuisse_Broschuere_ Richtlinien_Kindertagesstaetten_A5_low.pdf

Kuger, D.-P. S., \& Kluczniok, D.-P. K. (2009). Prozessqualität im Kindergarten - Konzept, Umsetzung und Befunde. In H.-G. Rossbach \& H.-P. Blossfeld (Eds.), Frühpädagogische Förderung in Institutionen (pp. pp. 159-178). doi:10.1007/9783-531-91452-7_11

La Paro, K. M., Hamre, B. K., \& Pianta, R. C. (2012). Classroom assessment scoring system (CLASS manual, toddler). Baltimore, MD: Brookes Publishing Co, Inc.

La Paro, K. M., Williamson, A. C., \& Hatfield, B. (2014). Assessing quality in toddler classrooms using the CLASS-toddler and the ITERS-R. Early Education and Development, 25(6), 875-893.

Layzer, J. I., \& Goodson, B. D. (2006). The "quality " of early care and education settings: Definitional and measurement issues. Evaluation Review, 30(5), 556-576.

Boo, F. L., Araujo, M. C., \& Tomé, R. (2016). How is child care quality measured? A toolkit. Washington: Inter-American Development.

Mashburn, A. J., Pianta, R. C., Hamre, B. K., Downer, J. T., Barbarin, O. A., Bryant, D., ... Howes, C. (2008). Measures of classroom quality in prekindergarten and children's development of academic, language, and social skills. Child Development, 79(3), 732-749.

Moller, A. C., Forbes-Jones, E., \& Hightower, A. D. (2008). Classroom age composition and developmental change in 70 urban preschool classrooms. Journal of Educational Psychology, 100(4), 741-753.

Muthén, L. K., \& Muthén, B. O. (2012). Mplus (version 7). Los Angeles, CA: Muthén \& Muthén.

NICHD. (2006). The NICHD study of early child care and youth development. Findings for children up to age 41/2 years (No. 05-4318). Author. Retrieved from http://www. nichd.nih.gov/publications/pubs/upload/seccyd_06.pdf

Pakarinen, E., Lerkkanen, M.-K., Poikkeus, A. -. M., Kiuru, N., Siekkinen, M., RaskuPuttonen, H., \& Nurmi, J.-E. (2010). A validation of the classroom assessment scoring system in finnish kindergartens. Early Education and Development, 21(1), 95-124.

Peisner-Feinberg, E. S., Burchinal, M. R., Clifford, R. M., Culkin, M. L., Howes, C., Kagan, S. L., \& Yazejian, N. (2001). The relation of preschool child-care quality to children's cognitive and social developmental trajectories through second grade. Child Development, 72(5), 1534-1553.

Perren, S., Frei, D., \& Herrmann, S. (2016). Pädagogische Qualität in frühkindlichen Bildungs- und Betreuungseinrichtungen in der Schweiz: Erste Erfahrungen und Befunde mit dem CLASS Toddler Beobachtungsverfahren. Frühe Bildung, 5(1), 3-12.

Perren, S., Herrmann, S., Iljuschin, I., Frei, D., Körner, C., \& Sticca, F. (2017). Child-centred educational practice in different early education settings: Associations with 
professionals' attitudes, self-efficacy, and professional background. Early Childhood Research Quarterly, 38, 137-148.

Phillips, D., Mekos, D., Scarr, S., McCartney, K., \& Abbott-Shim, M. (2000). Within and beyond the classroom door: Assessing quality in child care centers. Early Childhood Research Quarterly, 15(4), 475-496.

Pianta, R. C., Howes, C., Burchinal, M., Bryant, D., Clifford, R., Early, D., \& Barbarin, O. (2005). Features of pre-kindergarten programs, classrooms, and teachers: Do they predict observed classroom quality and child-teacher interactions? Applied Developmental Science, 9(3), 144-159.

Reyhing, Y., Frei, D., Burkhardt Bossi, C., \& Perren, S. (2019). Die Bedeutung situativer Charakteristiken und struktureller Rahmenbedingungen für die Qualität der unterstützenden Fachkraft-Kind-Interaktion in Kindertagesstätten. Zeitschrift Für Pädagogische Psychologie, 33(1), 33-47.

Slot, P. L., Boom, J., Verhagen, J., \& Leseman, P. P. M. (2017). Measurement properties of the CLASS Toddler in ECEC in The Netherlands. Journal of Applied Developmental Psychology, 48, 79-91.

Slot, P. L., Leseman, P. P. M., Verhagen, J., \& Mulder, H. (2015). Associations between structural quality aspects and process quality in Dutch early childhood education and care settings. Early Childhood Research Quarterly, 33, 64-76.

Sommer, A., \& Sechtig, J. (2016). Sozio-emotionale Interaktionsqualität vor dem Hintergrund einer erweiterten Altersmischung im Kindergarten. Frühe Bildung, 5 (1), 13-21.

Stamm, M. (2009). Frühkindliche Bildung in der Schweiz. Eine Grundlagenstudie im Auftrag der UNESCO-Kommission Schweiz (Monograph). Fribourg: University of Fribourg. Retrieved from http://edudoc.ch/record/31203/files/FBBE.pdf

Sundell, K. (1994). Instructional style, age span in child group and children's speech, cognitive, and socioemotional status. In F. Laevers (Ed.), Defining and assessing quality in early childhood education (pp. 27-38). Leuven: Leuven University Press.

Swiss Federal Statistical Office. (2014). Familien, Haushalte - Daten, Indikatoren: Europäischer Vergleich. Retrieved from http://www.bfs.admin.ch/bfs/portal/de/ index/themen/01/04/blank/key/04/04.html

Sylva, K., Melhuish, E., Sammons, P., Siraj-Blatchford, I., \& Taggart, B. (2004). The effective provision of pre-school education (EPPE) project: Findings from pre-school to end of key stage 1. Retrieved from http://research.ioe.ac.uk/portal/services/ downloadRegister/1960291/SSU_SF_2004_01_final_report_pre_school.pdf

Thomason, A. C., \& La Paro, K. M. (2009). Measuring the quality of teacher-Child interactions in toddler child care. Early Education and Development, 20(2), 285-304.

Tietze, W., Becker-Stoll, F., Bensel, J., Eckhardt, A. G., Haug-Schnabel, G., Kalicki, B., .. . Leyendecker, B. (2012). NUBBEK Nationale Untersuchung zur Bildung, Betreuung und Erziehung in der frühen Kindheit. Fragestellungen und Ergebnisse im Überblick. Retrieved from http://www.nubbek.de/media/pdf/NUBBEK\%20Broschuere.pdf

Tietze, W., Becker-Stoll, F., Bensel, J., Eckhardt, A. G., Haug-Schnabel, G., Kalicki, B., .. Leyendecker, B. (2013). Nationale Untersuchung zur Bildung, Betreuung und Erziehung in der frühen Kindheit (1st ed.). Weimar: Verlag das Netz.

Vandell, D. L., Belsky, J., Burchinal, M., Steinberg, L., \& Vandergrift, N.; NICHD Early Child Care Research Network. (2010). Do effects of early child care extend to age 15 years? 
Results from the NICHD study of early child care and youth development. Child Development, 81(3), 737-756.

Viernickel, S., \& Fuchs-Rechlin, K. (2016). Expertise. Fachkraft-Kind-Relationen und Gruppengrössen in Kindertageseinrichtungen. Grundlagen, Analysen, Berechnungsmodelle. In S. Viernickel, K. Fuchs-Rechlin, P. Strehmel, C. Preissing, J. Bensel, \& G. Haug-Schnabel (Eds.), Qualität für alle: Wissenschaftlich begründete Standards für die Kindertagesbetreuung (pp. 11-130). Freiburg: Verlag Herder GmbH. Vitiello, V. E., Booren, L. M., Downer, J. T., \& Williford, A. P. (2012). Variation in children's classroom engagement throughout a day in preschool: Relations to classroom and child factors. Early Childhood Research Quarterly, 27(2), 210-220.

von Suchodoletz, A., Fäsche, A., Gunzenhauser, C., \& Hamre, B. K. (2014). A typical morning in preschool: Observations of teacher-Child interactions in German preschools. Early Childhood Research Quarterly, 29(4), 509-519.

Wilson, H. K., Pianta, R. C., \& Stuhlman, M. (2007). Typical classroom experiences in first grade: The role of classroom climate and functional risk in the development of social competencies. The Elementary School Journal, 108(2), 81-96. 